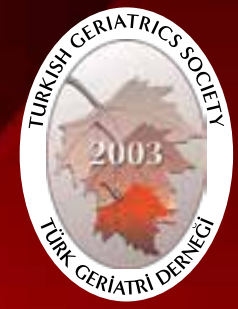

Turkish Journal of Geriatrics

DOI: 10.31086/tigeri.2019.101

2019; 22(3): 258-268

- Nailya BULATOVA ${ }^{1}$ (D)

- Eman ELAYEH ${ }^{1}$ (D

- Shayma ABDULLAH ${ }^{1}$ D

- Lana HALASEH ${ }^{2}$ (D)

- Sumaya ABULOHA ${ }^{1}$ D

- Maysam Abu RAQEEQ1 1 (D)

- Dana ALDAGHLISE² ${ }^{\text {ID }}$

- Ghadeer ALRBEIHAT ${ }^{2}$

CORRESPONDANCE

Nailya BULATOVA

The University of Jordan, School of Pharmacy,

Amman, Jordan.

Phone: +962799377784

Mobile: +962799377

e-mail: nyounes@ju.edu.jo

Received: 03/06/2019

Accepted: 28/08/2019

The University of Jordan, School of Pharmacy, Amman, Jordan

The University of Jordan, School of Medicine, Amman, Jordan.

\section{ASSESSMENT OF INAPPROPRIATE MEDICATION USE IN JORDANIAN ELDERLY HOSPITALIZED PATIENTS USING 2015 BEERS CRITERIA}

\section{Abstract}

Introduction: Inappropriate prescribing in the elderly is associated with poor clinical outcomes Using 2015 Beers criteria update, we aimed to evaluate the prevalence of inappropriate medication prescribing among elderly non-critically ill inpatients and to identify factors associated with inappropriate prescribing.

Materials and Method: This cross-sectional study included patients aged 65 years and ove admitted to the internal medicine and surgical wards. Using 2015 Beers criteria, we assessed potentially inappropriate medication prescribing, both prior to admission and during the hospital stay. Binary logistic regression analysis was used to assess the predictors of PIM.

Results: Among 351 patients, the use of at least one PIM was identified in $29.3 \%$ of cases prio to admission, $98 \%$ of which continued to receive PIMs during the hospital stay. Additionally, at least one potentially inappropriate medication was identified in $47.2 \%$ of patients during the hospital stay. The most common PIMs prior to admission were proton pump inhibitors ( $26.2 \%)$, followed by alpha blockers (5.1\%) and digoxin (4\%). Proton pump inhibitors were also the most common PIMs in the hospital (42.5\%), followed by alpha blockers (4.8\%) and metoclopramide (4.3\%).

According to the binary logistic regression analysis, factors that significantly affected PIM prescription in the hospital were the number of drugs prescribed in the hospital (odds ratio 1.222 $\mathrm{P}=0.001$ ) and medical ward admission (odds ratio $1.686, \mathrm{P}=0.035$ )

Conclusion: There is an alarmingly high prevalence of PIM use among Jordanian elderly patients, with polypharmacy being its major factor.

Keywords: Potentially inappropriate medication list; Aged; Prescription

ARAŞTIRMA

\section{HASTANEDE YATAN ÜRDÜN'LÜ YAŞLI HASTALARDA 2015 BEERS KRITERLERI KULLANILARAK UYGUNSUZ ILAÇ KULLANIMININ DEĞERLENDIRILMESI}

\section{$\ddot{O}_{z}$}

Giriş: Yaşlılarda uygunsuz reçeteleme ile kötü klinik sonuçlar arasında bir ilişki vardır. Bu çalışma güncellenen Beers 2015 kriterlerini kullanarak kritik olmayan yaşlı hastalar arasında uygunsuz ilaç kullanımının yaygınlığını değerlendirmeyi ve uygunsuz reçeteleme ile ilişkili faktörleri belirlemeyi amaçladı.

Gereç ve Yöntem: Bu kesitsel araştırmaya tıbbi ve cerrahi servislere yatııılan 65 yaş ve üzeri hastalar dahil edilmiştir. Beers 2015 kriterlerini kullanarak, hem hastaneye yatıştan önce hem de hastanesüreci sırasında, muhtemel uygunsuz ilaç reçetelemesini değerlendirdik. Muhtemel uygunsuz ilaç bağımsız değişkenlerini değerlendirmek için binary (ikili) lojistik regresyon analizi kullanılmıştır.

Bulgular: 351 hasta arasında, muhtemel uygunsuz olan en az bir ilacın kullanımı, hastaneye yatıştan önce vakaların \% 29,3'ünde tespit edilmiş, bunların \% 98 hastanede kalıs sırasında muhtemel uygunsuz ilaçları almaya devam etmiştir. Hastane sürecinde hastaların \% 47.2'sinde en az bir muhtemel uygunsuz ilaç tespit edildi. Hastaneye yatıştan önce en yaygın muhtemel uygunsuz ilaçlar proton pompası inhibitörleri idi (\% 26.2), bunları alfa blokerler (\% 5.1) ve digoksin (\% 4) takip etmekteydi. Proton pompa inhibitörleri ayrıca hastane sürecinde verilen en sık muhtemel uygunsuz ilaçlardı (\% 42,5), bunları alfa blokerleri $(\% 4,8)$ ve metoklopramid $(\% 4,3)$ takip etmekteydi.

Binary lojistik regresyon analizine göre, hastane sürecindeki muhtemel uygunsuz ilaçların reçetelenmesini önemli ölçüde etkileyen faktörler, hastanede reçetelenen ilaç sayısı (risk oranı 1,222 $P=0,001$ ) ve tıbbi servisine tedavi görmeydi (risk oranı 1,686, $P=0,035$ ).

Sonuç: Ürdünlü yaşı hastalar arasında muhtemel uygunsuz ilaçlar kullanımı endişe verici derecede yüksek yaygınlıktadır. Muhtemel uygunsuz ilaçlar ile ilişkili ana faktör çoklu ilaç kullanımıdı

Anahtar sözcükler: Muhtemel uygunsuz ilaç listesi; Yaşlılar; Reçete 


\section{INTRODUCTION}

Medication use in older adults is complex and challenging due to age-associated changes that include multiple morbidities, frailty, cognitive impairment, and other geriatric syndromes. Accordingly, the elderly often receive multiple medications and are at high risk of developing adverse effects (1).

Medications are considered to be potentially inappropriate for the elderly when the risk of harmful effects exceeds their potential benefit for the patient and when there is a safer, better tolerated, or more effective alternative (2).

There is an association between inappropriate prescribing in the elderly and mortality, need for additional healthcare services, adverse drug events, and decreased quality of life $(3,4)$. Several studies were conducted to assess appropriate medication prescription among elderly in different settings including the community $(5,6)$, primary care settings $(7,8)$, nursing homes (9), and hospitals (10-13).

The 2015 Beers criteria (AGS) (14) encompass a list of potentially inappropriate medication (PIM) classes for use in the elderly. Previous research suggested that the Beers criteria could detect more PIMs than both the earlier version and the STOPP_ START criteria (15).

To date, very few studies used 2015 AGS Beers criteria in the identification of PIMs among hospitalized patients (11-13).

\section{The Study Objective}

Using 2015 Beers criteria update, this study aimed to evaluate the prevalence of inappropriate medication prescribing among elderly non-critically ill inpatients and to identify factors associated with inappropriate prescribing.

\section{MATERIALS AND METHOD}

\section{Study design and data collection}

This cross-sectional study was conducted over 12 months between August 2016 and August 2017 at the Jordan University Hospital.

All consecutive patients aged 65 years and older admitted to the internal medicine and surgical wards were offered the opportunity to participate in the study. Critically ill patients were excluded. The study was compliant with the principles of the Declaration of Helsinki.

The study protocol was approved by the Jordan University Hospital Institutional Review Board.

The sample size calculation was conducted using OpenEpi software (Dean et al., 2013) (18). Based on the previous study by Gallagher et al. (2007) (5), the estimated study sample size should be 334 patients.

This study included a total of 351 patients, all of whom received detailed information about the study, including confidentiality and the anonymous nature of the data collected, before providing their consent to participation.

A clinical pharmacist performed data collection and determination of PIM by interviewing patients in addition to reviewing their medical records. In case of uncertainty of the PIM determination, a senior clinical pharmacist and an MD were consulted.

\section{Study Instrument}

Data collected during the interview included sociodemographic characteristics, the number of hospital admissions in the preceding year, and the pre-admission performance-based measure of independence in activities of daily living using the Katz Index (17). Self-rated health status was also assessed on a ten-point Likert-type scale with responses ranging from 1 (poor) to 10 (excellent). More data, including the length of hospital stay up to the day of data collection?, specific diagnoses, and comorbidities quantified by the Charlson comorbidity index score, were collected from medical records (18). All drugs prescribed prior to hospital admission and during the hospital stay were also registered.

Determination of Potentially Inappropriate Medication (PIM) 
PIMs were scanned using the 2015 "Beers Criteria for Potentially Inappropriate Medication Use in Older Adults" including prior-to-admission (PTA) medications and those prescribed during the hospital stay, and doses were assessed when necessary. In addition, medical records were reviewed to determine the reasons behind prescription and, subsequently, to reassess the appropriateness of each PIM.

\section{Statistical analysis}

All statistical analyses were conducted using the Statistical Package for the Social Sciences (SPSS) 20. Univariate analysis was carried out using Chi-square test for categorical variables or an independent t-test for continuous variables to determine an association between the parameters studied and PIM prescription. A two-sided P-value $<0.05$ was considered to be statistically significant.

All variables found to have a significant association $(P<0.05)$ with $\mathrm{PIM}$ prescription in the hospital by the bivariate analysis were entered into a binary logistic regression analysis to assess the predictors of PIM.

\section{RESULTS}

Three hundred and fifty-one patients were included, $51 \%$ of whom were males. The mean age was $73.7 \pm 5.8$ years, the mean Charlson comorbidity index of study subjects was $5.4 \pm 1.6$, and the mean Katz Index of Independence in Activities of Daily Living was $6.7 \pm 1.3$ (Table 1). The mean number of prescribed drugs in the hospital was $8.1 \pm 3.8$ (Table 2). The most common comorbidities were hypertension (74.4\%), diabetes (58.7\%), and chronic kidney disease (34.2\%).

The use of at least one PIM was identified in $29.4 \%$ of elderly patients PTA, $98.1 \%$ of whom continued to receive PIMs during the hospital stay (Table 2). The most common inappropriately prescribed medications PTA were proton pump inhibitors (PPIs) (26.2\%), followed by alpha blockers (5.1\%) and digoxin (4\%) (Table 3).
Table 1. Demographic characteristics of patients ( $N=351)$.

\begin{tabular}{|l|r|}
\hline Gender, [N (\%)] & \\
\hline Male & $179(51.0)$ \\
\hline Age (mean \pm SD) (min-max) & $73.7 \pm 5.8(65-$ \\
\hline $65-69$ & $87(24.8)$ \\
\hline $70-74$ & $116(33.0)$ \\
\hline $75-79$ & $79(22.5)$ \\
\hline $80-84$ & $52(14.8)$ \\
\hline$>85$ & $17(4.8)$ \\
\hline Occupation [N (\%)] & \\
\hline Retired & $168(47.9)$ \\
\hline Housewife & $168(47.9)$ \\
\hline Employee & $15(4.3)$ \\
\hline Educational level [N (\%)] & $278(45.1 \%)$ \\
\hline No formal education & $219(62.4)$ \\
\hline Elementary school & $38(10.8)$ \\
\hline Middle school & $10(2.8)$ \\
\hline High school & $23(6.6)$ \\
\hline Bachelor or higher degree & $38(10.8)$ \\
\hline Smoking status [N (\%)] & \\
\hline Smoker & $277(78.9)$ \\
\hline Nonsmoker & \\
\hline Ex-smoker & \\
\hline
\end{tabular}

At least one PIM prescription during the hospital stay was received by $47.3 \%$ of patients.

Similar to prior to admission, PPls were also the most common PIMs during the hospital stay 
(42.5\%), followed by alpha blockers (4.8\%) and metoclopramide (4.3\%) (Table 3).

As shown by the univariate analysis, PIM prescription PTA was associated with a higher total number of drugs, a higher Charlson comorbidity index $(P<0.005$ for both), admission to internal medicine ward $(P<0.05)$, hypertension $(P=0.044)$, ischemic heart disease $(P=0.033)$, history of myocardial infarction $(P=0.044)$, cerebrovascular disease $(P=0.016)$, or diabetes mellitus $(P=0.06)$ (Table 4).

Furthermore, during the hospital stay, PIM prescription was also associated with a higher total number of drugs both PTA and during the hospital stay $(\mathrm{P}<0.005$ in each case) as well as with a higher Charlson comorbidity index $(P=0.018)$, internal medicine ward admission $(P<0.005)$, or cerebrovascular disease $(P=0.02)$ (Table 4).

Binary logistic regression analysis revealed that the only variable that affected PIM prescription PTA was the total number of drugs received (OR 1.4, $\mathrm{P}<0.005)$.

Conversely, factors that significantly affected PIM prescription in the hospital were the number of drugs prescribed (OR 1.222, $\mathrm{P}=0.001$ ) and admission to the medical ward (OR 1.686, $\mathrm{P}=0.035$ ) (Table 5).

\section{DISCUSSION}

In this cross-sectional study conducted in Jordan using 2015 Beers criteria, we demonstrate a high prevalence of PIM use among elderly patients admitted to medical and surgical wards, both prior to admission and during the hospital stay.

The major study strength is that it is one of the first studies worldwide to assess the PIM prevalence among hospitalized elderly patients utilizing 2015 Beers criteria (11-13), the most updated prescribing assessment tool for elderly at the time of the study conduction. The criteria utilize evidence-based standards of the Institute of Medicine and its partnership with the AGS to update it regularly.
The changes in the 2015 AGS Beers criteria (14) from the previous 2012 version include the addition of two tables, one describing drug-drug interactions and the other illustrating medications that require dose reduction or avoidance in renal impairment. The 2015 AGS Beers list also contains five new medications or drug classes added.

Similar to our results of $29.3 \%$ receiving PIM PTA, $27.6 \%$ of community-dwelling elderly patients received at least one PIM in an Iranian study (19). In a Canadian study, a higher proportion (37\%) of older people filled 1 or more inappropriate prescription (20). Notably, the above two studies used previous versions of Beers criteria. In the Canadian study, (20) a higher proportion of women (42.2\%) than men (31.0\%) filled potentially inappropriate prescriptions in the high-data coverage provinces, as opposed to our finding of lack of gender differences in PIM prescription. In a recently published study from Jordan, the prevalence of PIM in outpatients was much higher (62.5\%) (21), probably due to the fact that the patients included in that study reside in rural area with less access to specialized medical care.

Our results show that, prior to admission, the most commonly prescribed PIMs were PPIs (26.2\%). As this class of medications was not included in previous versions of Beers criteria, the most common PIM class in Iran was antihistamines (19), while in Canada benzodiazepines and other hypnotics, along with nitrofurantoin and estrogens in women, contributed the most to both frequency and cost of PIMs (20).

In this study, $47.2 \%$ of patients received at least one PIM prescription during the hospital stay. The PIM prevalence in our study was in agreement with the data from the US study $(49 \%$ among elderly admitted with one or more of seven common medical diagnoses) (22), but lower than in a recent prospective cohort Italian study on hospitaldischarged patients where the PIM prevalence was 63\% (13). In a study from Brazil (23), the PIM prevalence was markedly higher (95.5\%), probably due to the difference in inclusion criteria (the 
authors defined elderly as individuals 60 years and above). In contrast, PIM prescription rates in our study were higher than those reported in Ireland (32\%) (5), where generally acutely ill elderly patients were assessed using 2003 Beers criteria and patients received less number of medications (mean=5). Lower PIM prevalence was also reported among older emergency department patients in the United States (16.8\%) (24).

Such marked variability in the prevalence of PIM prescription might be related to the difference in disease management guidelines and hospital drug formularies, study design (cross-sectional vs. retrospective cohort or prospective cohort), characteristics of the population groups (e.g., mean age, mean number of medications, generally inhospital as opposed to critically ill patients), and the inclusion of PPI use duration for the first time in 2015 Beers criteria.

Notably, the most commonly prescribed PIM classes prior to hospital admission paralleled those in the hospital. Furthermore, the number of individuals with PIMs increased from 29.3\% PTA to $47.2 \%$ during the hospital stay in our study, as compared with the increase only from $62.3 \%$ to $66.6 \%$ in a recent retrospective cohort study from Brazil (25).

Ofimportance, PPIs were again the most common PIMs during the hospital stay. De Oliviera et al. (2014) (21) also found that omeprazole, which at that time was not listed in the Beers criteria, was widely used in elderly patients. Moreover, the avoidance of PPI use beyond 8 weeks without justification was added to the 2015 Beers criteria. This was based on the evidence that supports an association between PPI exposure and Clostridium difficile infection, bone loss, and fractures (14). Among hospitalized Swiss patients in the internal medicine ward, PPIs were also prescribed frequently without clear indication, but the authors used STOPP criteria (26).

An important finding in our study was that all PIM prescribed PTA were continued at the hospital. This indicates that physicians at the hospital seldom review the medications that patients were receiving prior to admission.

As shown in our study, PIM prescription, both PTA and during the hospital stay, was more frequent in patients who received a higher total number of drugs. Earlier studies demonstrated an association between the total number of drugs received and PIM use, both in outpatient $(3)$ and inpatient $(5,24)$ settings. In a recent prospective cohort Italian study on hospital-discharged patients, the PIM prevalence was associated with psychiatric-behavioral disorders, the number of daily taken medications, and long-term care discharge, whereas better functional performance was protective (13).

Therefore, our study confirmed the earlier findings that polypharmacy is the major factor involved in PIM prescription for the elderly in both community and hospital settings. Overall, polypharmacy and inappropriate medication use are associated with adverse health outcomes, including mortality, hospitalization, falls, and cognitive impairment (4).

The association of PIM with admission to the internal medicine ward may be related to more complex medication regimens in patients receiving treatment in such ward as compared to surgical patients.

Some reports demonstrated improved pharmacotherapy outcomes for the elderly with proactive participation of pharmacists in performing systematic medication reviews and in actively educating other healthcare professionals such as physicians and nurses $(13,27)$. Further studies should be conducted to assess the impact of clinical pharmacist or clinical pharmacologist intervention on the PIM prevalence in different clinical settings.

Our study has some limitations:

1. Cross-sectional study nature does not allow to detect which factors associated with PIM are causal.

2. The Beers criteria were developed to assess PIM for the pharmaceutical products used in the USA. Thus, we might have underestimated the 
frequency of PIM for products not in use in the USA or overestimated the frequency of those not in use in Jordan.

3. PTA medications were reported by patients during a structured interview, which might have resulted in recall bias.

4. The study sample might not be representative of Jordan since patients may receive relatively high-quality treatment in a teaching hospital. Thus, additional studies should be performed to address PIM prescription in other health sectors in Jordan.

5. The study did not investigate the association between PIMs and clinical outcome, e.g., actual adverse effects, including falls, in elderly patients. Further studies are needed to clarify the clinical impact of PIMs in the elderly population.

6. The assessment of PIMs was based only on one tool, Beers criteria. However, as mentioned above, the updated Beers list could detect more PIMs than older versions of Beers and STOPP-START tools.

\section{CONCLUSIONS}

There is an alarmingly high prevalence of PIM use among Jordanian elderly patients, with polypharmacy being its major factor.

\section{ACKNOWLEDGMENTS}

This study was funded by the Deanship of Academic Research and Quality Assurance, The University of Jordan [grant \# 3/2014-2015].

The authors are grateful to the staff of the JUH and the participant patients.

\section{CONFLICT OF INTEREST}

The authors declare that they do not have a conflict of interest.

Table 2. Clinical characteristics of patients $(N=351)$.

\begin{tabular}{|c|c|}
\hline Self-rated health status* [mean \pm SD] [min-max] & $5.01 \pm 1.7$ \\
\hline Length of hospital stay, days [mean \pm SD] & $3.9 \pm 5.0$ \\
\hline \multicolumn{2}{|l|}{ Reason of hospitalization [N (\%)] } \\
\hline $\begin{array}{l}\text { Internal medicine admission } \\
\text { Abdominal pain }\end{array}$ & $\begin{array}{r}201(57.3) \\
17(8.5) \\
\end{array}$ \\
\hline Anemia & $5(2.5)$ \\
\hline Neoplasia and chemotherapy & $6(3.0)$ \\
\hline Cerebrovascular disease (transient ischemic attack or stroke) & $8(4.0)$ \\
\hline Kidney disease (chronic kidney disease or acute kidney injury) & $7(3.5)$ \\
\hline Cardiac causes (heart failure, acute coronary syndromes, arrhythmias) & $25(12.4)$ \\
\hline Diabetes mellitus and its complications & $6(3.0)$ \\
\hline Dyspnea (including chronic obstructive pulmonary disease exacerbation) & $40(19.9)$ \\
\hline Acute infection (including urinary tract infection, pneumonia, cellulitis) & $47(23.4)$ \\
\hline Others (e.g., dizziness, back pain, gastrointestinal bleeding, epistaxis) & 40 (19.9) \\
\hline Surgical ward admission & $150(42.7)$ \\
\hline
\end{tabular}




\begin{tabular}{|c|c|}
\hline Orthopedic surgery & $54(36.0)$ \\
\hline Urosurgery & $16(10.7)$ \\
\hline Abdominal surgery & $15(10.0)$ \\
\hline Diabetic foot ulcer (DFU) & $20(13.3)$ \\
\hline Ophthalmic surgery & $18(12.0)$ \\
\hline Others (e.g., thyroidectomy, open heart surgery, brain tumor surgery, varicose vein surgery) & $27(18.0)$ \\
\hline Number of drugs received in the hospital [mean \pm SD] & $8.1 \pm 3.8$ \\
\hline Number of drugs received PTA [mean \pm SD] & $5.6 \pm 3.0$ \\
\hline \multicolumn{2}{|l|}{ Number of patients who were prescribed PIM PTA [N (\%)] } \\
\hline No PIM & $248(70.7)$ \\
\hline One PIM & $95(27.1)$ \\
\hline Two PIMs & $8(2.2)$ \\
\hline $\begin{array}{l}\text { Number of patients continuing inappropriate medications during the hospital stay } \\
{[\mathrm{N}(\%)+]}\end{array}$ & $101(98.1)$ \\
\hline \multicolumn{2}{|l|}{ Number of patients who were prescribed PIM during the hospital stay [N (\%)] } \\
\hline No PIM & $185(52.8)$ \\
\hline One PIM & $137(39.0)$ \\
\hline Two PIMs & $24(6.8)$ \\
\hline Three or more PIMs & $5(1.4)$ \\
\hline \multicolumn{2}{|l|}{ Number of patients with previously diagnosed comorbid conditions [N (\%)] } \\
\hline Hypertension & $261(74.4)$ \\
\hline Atrial fibrillation & $24(6.9)$ \\
\hline Coronary artery disease & $92(26.2)$ \\
\hline Previous myocardial infarction & $23(6.6)$ \\
\hline Congestive heart failure & $34(9.7)$ \\
\hline Cerebrovascular disease & $26(7.4)$ \\
\hline Chronic obstructive pulmonary disease & $12(3.40$ \\
\hline Diabetes mellitus & $206(58.7)$ \\
\hline
\end{tabular}

*self-rated health status ranges from 1 (poor) to 10 (excellent)

tproportion of patients who continued in the hospital with the same PIM as prior to admission

$\ddagger$ Katz Index ranges from $7=$ high (patient independent) to $0=$ low (patient very dependent)

PIM, potentially inappropriate medication

PTA, prior to admission 
Table 3. . Number of PIM identified by 2015 Beers criteria prior to admission and during the hospital stay.

\begin{tabular}{|c|c|c|}
\hline \multirow[b]{2}{*}{ Drug/drug class } & \multicolumn{2}{|c|}{$\mathbf{N}(\%)^{*}$} \\
\hline & Prior to admission & During the hospital stay \\
\hline $\begin{array}{l}\text { PIMs } \\
\text { Anticholinergics }\end{array}$ & $10(2.8)$ & $14(4.0)$ \\
\hline Alpha blockers $\dagger$ & $18(5.1)$ & $17(4.8)$ \\
\hline Digoxin & $14(4.0)$ & $14(4.0)$ \\
\hline $\begin{array}{l}\text { Antipsychotics for behavioral and psychotic symptoms of } \\
\text { dementia }\end{array}$ & $1(0.3)$ & $1(0.3)$ \\
\hline TCA & - & $2(1.2)$ \\
\hline $\begin{array}{l}\text { Short-intermediate-acting benzodiazepines } \\
\text { (Bromazepam) } \\
\text { Long-acting benzodiazepines (chlordiazepoxide) }\end{array}$ & $2(0.6)$ & $\begin{array}{l}2(0.6) \\
2(0.6)\end{array}$ \\
\hline Glyburide (glibenclamide) & $7(2.0)$ & $6(1.7)$ \\
\hline Metoclopramide & - & $15(4.3)$ \\
\hline PPIsł & $92(26.2)$ & 149 (42.5) \\
\hline Meperidine & - & $2(0.6)$ \\
\hline NSAIDs & - & w1 (0.3) \\
\hline Drugs to be used with caution & $19(5.5)$ & $19(5.5)$ \\
\hline $\begin{array}{l}\text { Aspirin (as a primary prevention of cardiovascular disease in } \\
\text { patients older than } 80 \text { years) }\end{array}$ & $1(0.3)$ & $1(0.3)$ \\
\hline Isosorbide dinitrate & $18(5.2)$ & $18(5.2)$ \\
\hline Drug interactions that should be avoided & 0 & 0 \\
\hline
\end{tabular}

\section{*Valid percent}

†Indicated for treatment of benign prostate hyperplasia, not as a routine treatment of hypertension

‡Appropriate prescription of PPI in medical ward patients include one of the following: treatment of duodenal ulcer, gastric ulcer, gastroesophageal reflux disease, erosive esophagitis, pathological hypersecretory conditions, prevention of NSAID-induced ulcer

$\mathrm{PIM}$, potentially inappropriate medications

PPI, proton pump inhibitors

TCAs, tricyclic antidepressants 
Table 4. Factors associated with PIM prescription.

\begin{tabular}{|c|c|c|c|c|c|c|}
\hline \multirow[b]{2}{*}{ Variables } & \multicolumn{3}{|c|}{ PIM prescribed PTA } & \multicolumn{3}{|c|}{ PIM prescribed in the hospital } \\
\hline & $\begin{array}{r}\text { Yes } \\
(N=103) \\
\end{array}$ & $\begin{array}{r}\text { No } \\
(\mathrm{N}=248) \\
\end{array}$ & \multirow{2}{*}{$P^{*}$} & $\begin{array}{r}\text { Yes } \\
(N=166)\end{array}$ & $\begin{array}{r}\text { No } \\
(\mathrm{N}=185) \\
\end{array}$ & \multirow[t]{2}{*}{$P *$} \\
\hline Continuous & \multicolumn{2}{|c|}{ Mean \pm SD } & & \multicolumn{2}{|c|}{ Mean \pm SD } & \\
\hline Age & $73.8 \pm 6.3$ & $73.7 \pm 5.5$ & 0.818 & $73.7 \pm 5.8$ & $73.7 \pm 5.7$ & 0.930 \\
\hline Number of drugs prescribed PTA & $7.5 \pm 2.7$ & $4.8 \pm 2.7$ & $<0.005$ & $6.5 \pm 3.0$ & $4.8 \pm 2.7$ & $<0.005$ \\
\hline Number of drugs received in hospital & & & & $9.6 \pm 3.6$ & $6.8 \pm 3.5$ & $<0.005$ \\
\hline Length of hospital stay, days & & & & $4.4 \pm 5.0$ & $3.4 \pm 4.9$ & 0.069 \\
\hline Charlson comorbidity index score & $5.9 \pm 1.6$ & $5.2 \pm 1.5$ & $<0.005$ & $5.6 \pm 1.6$ & $5.2 \pm 1.5$ & 0.018 \\
\hline Katz Index of Independence & $6.7 \pm 1.2$ & $6.6 \pm 1.4$ & 0.542 & $6.7 \pm 1.3$ & $6.7 \pm 1.3$ & 0.954 \\
\hline Categorical variables & \multicolumn{2}{|c|}{$\mathrm{N}(\%)$} & $\mathrm{P}+$ & \multicolumn{2}{|c|}{$\mathrm{N}(\%)$} & $\mathrm{P}+$ \\
\hline \multicolumn{7}{|l|}{ Gender } \\
\hline Males & $45(43.6)$ & $134(54.0)$ & \multirow{2}{*}{0.078} & $78(47.0)$ & $101(54.6)$ & \multirow{2}{*}{0.094} \\
\hline Females & $58(56.3)$ & $114(46.0)$ & & 88 (53.) & $84(45.4)$ & \\
\hline \multicolumn{7}{|l|}{ Hospital ward } \\
\hline Surgical ward & & & & $52(31.3)$ & $98(53)$ & \multirow{2}{*}{$<0.005$} \\
\hline Internal medicine & & & & $114(68.7)$ & $87(47.0)$ & \\
\hline \multicolumn{7}{|l|}{ Occupation } \\
\hline Retired & $42(40.8)$ & $126(50.8)$ & \multirow{3}{*}{0.231} & $71(42.8)$ & $97(52.4)$ & \multirow{3}{*}{0.095} \\
\hline Housewife & $56(54.4)$ & $112(45.2)$ & & $85(51.2)$ & $83(44.9)$ & \\
\hline Employee & $5(4.9)$ & $10(4.0)$ & & $10(6.0)$ & $5(2.7)$ & \\
\hline \multicolumn{7}{|l|}{ Occupation } \\
\hline Hypertension & $84(81.6)$ & $177(71.4)$ & 0.047 & $127(76.5)$ & $134(72.4)$ & 0.383 \\
\hline Atrial fibrillation & $11(10.7)$ & $13(5.2)$ & 0.062 & $12(7.2)$ & $12(6.5)$ & 0.771 \\
\hline Ischemic heart disease & $35(34.0)$ & $57(23.0)$ & 0.033 & $45(27.1)$ & $47(25.4)$ & 0.717 \\
\hline History of myocardial infarction & $11(10.7)$ & $12(4.8)$ & 0.044 & $11(6.6)$ & $12(6.5)$ & 0.958 \\
\hline Congestive heart failure & $14(13.6)$ & $20(8.1)$ & 0.114 & $21(12.7)$ & $13(7.0)$ & 0.078 \\
\hline Cerebrovascular disease & $13(12.6)$ & $13(5.2)$ & 0.016 & $18(10.8)$ & $8(4.3)$ & 0.020 \\
\hline Diabetes mellitus & $72(69.9)$ & $134(54.0)$ & 0.006 & $104(62.7)$ & $102(55.1)$ & 0.153 \\
\hline Chronic kidney disease & $40(38.8)$ & $80(32.2)$ & 0.237 & $60(36.1)$ & $60(32.4)$ & 0.464 \\
\hline
\end{tabular}

${ }^{*}$ calculated using independent-sample t-test, $\uparrow$ calculated using Chi-square test

PIM - potentially inappropriate medication

PTA - prior to admission 
Table 5. Results of logistic regression analysis for factors associated with PIM prescription in the hospital.

\begin{tabular}{|l|r|r|r|r|r|}
\hline Variable & Ba & SE & P & OR & $\begin{array}{r}95 \% \\
\text { Confidence } \\
\text { interval }\end{array}$ \\
\hline Constant & 1.488 & 0.680 & 0.029 & 0.226 & - \\
\hline Number of drugs prescribed PTA & 0.027 & 0.071 & 0.711 & 0.974 & $0.847-1.120$ \\
\hline $\begin{array}{l}\text { Number of drugs prescribed in the } \\
\text { hospital }\end{array}$ & -0.201 & 0.058 & $0.001^{\star}$ & 1.222 & $1.091-1.372$ \\
\hline Charlson comorbidity index & -0.038 & 0.080 & 0.963 & 1.038 & $0.887-1.215$ \\
\hline Hospital ward (internal medicine) & -0.522 & 0.247 & $0.035^{\star}$ & 1.686 & $1.038-2.7322$ \\
\hline Cerebrovascular disease & 0.648 & 0.460 & 0.159 & 0.523 & $0.212-1.289$ \\
\hline
\end{tabular}

aStandardized coefficient.

*Significant at $\mathrm{P}$-value $<0.05$.

\section{REFERENCES}

1. Brahma DK, Wahlang JB, Marak MD, Sangma M. Adverse drug reactions in the elderly. J Pharmacol Pharmacother 2013;4(2):91-4. (PMID: 23761706).

2. Spinewine A, Schmader KE, Barber $N$, et al. Appropriate prescribing in elderly people: how well can it be measured and optimised? Lancet 2007;370(9582):173-84. (PMID: 17630041).

3. Onder G, Landi F, Cesari M, et al. . Inappropriate medication use among hospitalized older adults in Italy: results from the Italian Group of Pharmacoepidemiology in the Elderly. Eur J Clin Pharmacol 2003;59(2):157-62. (PMID: 12734610).

4. Lau DT, Kasper JD, Potter DE, Lyles A, Bennett RG. Hospitalization and death associated with potentially inappropriate medication prescriptions among elderly nursing home residents. Arch Intern Med 2005;165(1):68-74. (PMID: 15642877).

5. Gallagher PF, Barry PJ, Ryan C, Hartigan I, O'Mahony $D$. Inappropriate prescribing in an acute ill population of elderly patients as determined by Beers Criteria. Age Ageing 2008;37(1):96-101. (PMID: 17933759).

6. Buck MD, Atreja A, Brunker $C P$, et al. Potentially inappropriate medication prescribing in outpatient practices: prevalence and patient characteristics based on electronic health records. Am J Geriatr Pharmacother 2009;7(2):84-92. (PMID: 19447361).
7. Bregnhøj L, Thirstrup S, Kristensen MB, Bjerrum L, Sonne J. Prevalence of inappropriate prescribing in primary care. Pharm World Sci 2007;29(3):109-15. (PMID: 17353970).

8. Ryan C, O'Mahony D, Kennedy J, Weedle P, Byrne S. Potentially inappropriate prescribing in an Irish elderly population in primary care. Br J Clin Pharmacol 2009;68(6):936-47. (PMID: 20002089).

9. Colloca $\mathrm{G}$, Tosato $\mathrm{M}$, Vetrano $\mathrm{DL}$, et al. Inappropriate drugs in elderly patients with severe cognitive impairment: results from the shelter study. PLoS One 2012;7(10): e46669. (PMID: 23056394).

10. Wahab MS, Nyfort-Hansen K, Kowalski SR. Inappropriate prescribing in hospitalised Australian elderly as determined by the STOPP criteria. Int J Clin Pharm 2012;34(6):855-62. (PMID: 22864867).

11. Juliano ACDSRS, Lucchetti ALG, Silva JTSD, et al. Inappropriate Prescribing in Older Hospitalized Adults: A Comparison of Medical Specialties. J Am Geriatr Soc 2018;66(2):383-388. (PMID: 28975608).

12. Komagamine J. Prevalence of potentially inappropriate medications at admission and discharge among hospitalised elderly patients with acute medical illness at a single centre in Japan: a retrospective cross-sectional study. BMJ Open 2018;8(7):e021152. (PMID: 30030316). 
13. Bo M, Quaranta V, Fonte G, Falcone $Y$, Carignano G, Cappa G.. Prevalence, predictors and clinical impact of potentially inappropriate prescriptions in hospital-discharged older patients: A prospective study. Geriatr Gerontol Int 2018;18(4):561-8. (PMID: 29265509).

14. The American Geriatrics Society 2015 Beers Criteria Update Expert Panel. American Geriatrics Society 2015 Updated Beers Criteria for Potentially Inappropriate Medication Use in Older Adults. J Am Geriatr Soc 2015;63(11):2227-46. (PMID: 26446832).

15. Blanco-Reina E, Ariza-Zafra G, Ocaña-Riola R, León-Ortiz M.. 2012 American Geriatrics Society Beers criteria: enhanced applicability for detecting potentially inappropriate medications in European older adults? A comparison with the screening tool of older person's potentially inappropriate prescriptions. J Am Geriatr Soc 2014;62(7):1217-23. (PMID: 24917083).

16. Dean AG, Sullivan KM, Soe MM. OpenEpi: Open Source Epidemiologic Statistics for Public Health, Version. www.OpenEpi.com, updated 2013/04/06, accessed 2019/08/05.

17. Katz S. Assessing self-maintenance: activities of daily living, mobility, and instrumental activities of daily living. J Am Geriatr Soc 1983;31(12):721-7. (PMID: 6418786).

18. Charlson ME, Pompei P, Ales KL, MacKenzie CR. A new method of classifying prognostic comorbidity in longitudinal studies: development and validation. J Chronic Dis 1987;40(5):373-83. (PMID: 3558716).

19. Azoulay L, Zargarzadeh A, Salahshouri Z, Oraichi D, Bérard A. Inappropriate medication prescribing in community-dwelling elderly people living in Iran. Eur J Clin Pharmacol 2005;61(12):913-9. (PMID: 16307268).

20. Morgan SG, Hunt J, Rioux J, Proulx J, Weymann D, Tannenbaum C. Frequency and cost of potentially inappropriate prescribing for older adults: a crosssectional study. CMAJ OPEN 2016;4(2):E346-51. (PMID: 27398383).
21. Al-Azayzih A, Alamoori R, Altawalbeh SM. Potentially inappropriate medications prescribing according to Beers criteria among elderly outpatients in Jordan: a cross sectional study. Pharm Pract (Granada). 2019;17(2):1439. (PMID: 31275497).

22. Rothberg MB, Pekow PS, Liu F, et al. Potentially inappropriate medication use in hospitalized elders. J Hosp Med 2008;3(2):91-102. (PMID: 18438805).

23. de Oliveira Alves C, Schuelter-Trevisol F, Trevisol DJ. Beers criteria-based assessment of medication use in hospitalized elderly patients in southern Brazil. J Family Med Prim Care 2014;3(3):260-5. (PMID: 25374866).

24. Meurer WJ, Potti TA, Kerber KA, et al. Potentially inappropriate medication utilization in the emergency department visits by older adults: analysis from a nationally representative sample. Acad Emerg Med 2010;17(3):231-7. (PMID: 20370754).

25. Faustino CG, Passarelli MC, Jacob-Filho W. Potentially inappropriate medications among elderly Brazilian outpatients. Sao Paulo Med J 2013;131(1):19-26. (PMID: 23538591).

26. Urfer $M$, Elzi $L$, Dell-Kuster $S$, Bassetti $S$. Intervention to Improve Appropriate Prescribing and Reduce Polypharmacy in Elderly Patients Admitted to an Internal Medicine Unit. PLoS ONE 2016;11(11):e0166359. (PMID: 27902720).

27. Spinewine A, Fialová D, Byrne $S$. The role of the pharmacist in optimizing pharmacotherapy in older people. Drugs Aging 2012;29(6):495-510. (PMID: 22642783). 